\title{
The rescue of the genre through historiographical confusion: María Fernández Coronel, Queen María de Molina's governess
}

\section{El rescate del género a través de la confusión historiográfica: María Fernández Coronel, aya de la Reina María de Molina}

\author{
Alicia Marchant RIVERA \\ Universidad de Málaga \\ amr@uma.es \\ http://orcid.org/0000-0002-1153-1734
}

Fecha de recepción: 25-5-2020

Fecha de aceptación: 15-10-2020

\begin{abstract}
The main connotation accompanying María Fernández Coronel as a historical figure is to have become Queen María de Molina's personal governess. In face of numerous studies dedicated to the medieval queen, however, her governess remains blurred and opaque in most of these publications. A portion of historiography referred indirectly to this particular figure has spread some uncertainty, due to the confusion with other women of her same lineage, with the same name and surnames (Ambrosio de Morales, Jacobo de Castro, the monk Arturo...); and this has contributed to the shortage or the absence of monographic works dedicated to the governess' figure. We will analyse some episodes of María de Molina's reign in which María Fernández Coronel's abilities were notorious and we will contemplate scenes where the silence or the ability of being diplomatic agent in front of the abuse of authority. In this way we will be able to state that queen and governess represent a historical practice referred to the idea of pathway, relationship based on difference.
\end{abstract}

Key words: María de Molina, María Fernández Coronel, lineage, historiographical confusión Toponyms: Castile

Period: Middle Ages.

\section{RESUMEN}

La principal connotación que ha acompañado a María Fernández Coronel como personaje histórico ha sido la de figurar en los anales como el aya de la reina María de Molina. Frente a los numerosos estudios dedicados a la soberana medieval, la figura de su aya permanece opaca y olvidada en la mayoría de estas publicaciones. Gran parte de la historiografía que incorpora referencias a la figura de María Fernández Coronel (Ambrosio de Morales, Jacobo de Castro, el Monje Arturo...) ha contribuido con sus erróneos datos a que escaseen, o incluso no existan, trabajos íntegros dedicados a esta figura histórica femenina. En el presente estudio analizaremos 
algunos episodios del reinado de María de Molina en los que se destacaron las habilidades de María Fernández Coronel. Cualidades como el silencio, o el constituirse en improvisado agente diplomático, se destacarán frente al abuso de la autoridad. De esta forma se podrá concluir en que reina y aya representan una práctica histórica basada en la idea de camino, en la idea de relación basada en la diferencia.

Palabras clave: María de Molina, María Fernández Coronel, linaje, confusión historiográfica Topónimo: Castilla

Período: Edad Media.

\section{THE SHADOW OF THE ORIGINS AND THE CONFUSION OF NAMES}

María Fernández Coronel was a lady of noble cause, owner of a large fortune and with of some personal abilities that may be summarised in her tact and discretion, abilities forming part of the quintessential pattern of her deep emotional intelligence. The main connotation that has accompanied her throughout her life is the fact that she became Queen María de Molina's personal governess, a role which, along with some additional ones, will be analysed in this work.

The presence of numerous titles related to Queen María de Molina on academic and informative publications during the last decades (Valle Curieses, 2000; Arteaga, 2005; Fuente Pérez, 2003; Márquez de la Plata, 2000; Álvarez, 2003; Arauz Mercado, 2007; Gaibrois de Ballesteros, 1967) evidences that she has continued to deserve the attention in monographs and book chapters; however, María Fernández Coronel, her governess, with a crucial value in many episodes of her reign, remains blurred and opaque, always discreetly in the background, in most of these publications. And whenever a historian manages to do more justice to her name, as in the case of Francisco Layna, he does it so partially, focusing on the process of creation of convents by this lady in the city of Guadalajara (Layna, 2010).

In addition to this fact, it has to be stated that, for a long time, the historiography that referred indirectly to this particular figure has spread some uncertainty, due to the confusion with other women of her same lineage, with the same name and surnames. This is the case of the chronicler Alonso Núñez de Castro (1653), who makes a confusion between her and her great-granddaughter María Fernández Coronel, wife of Juan de la Cerda (Pérez Arribas, 2000: 26-27; Moreri, 1753) and daughter of Alonso — Lord of Aguilar - and Doña Elvira Alfonso de Biedma (Real Monasterio, 1930). This María Fernández Coronel, known in the historiographic context as the one from Seville, is indeed referred to as the wife of Juan de la Cerda, nobleman whose execution was ordered by Peter the Cruel as just punishment for his continuous betrayals (Arana de Valflora, 1791). When she was a widow, she retreated to the Santa Clara convent in Seville, founding later, in the same city, the Santa Inés convent (Ortiz de Zúñiga, 1796), where her corpse is kept with some blemish on her face that gave rise to the legend according to which they were the result of burning oil thrown to destroy her beauty, which provoked sinful desires in the just monarch (Layna, 2010: 63; Matute and Gaviria, 1827). This María Fernández Coronel was the one who materialised the union of two noble lineages which had just settled down in the Alcarria in the beginning of the $14^{\text {th }}$ century (Sánchez Saus, 1989: 493; 2009: 158)ํ․

1 Fernán Ruiz de Biedma, whose wife and him were Infante Philip's mistress and master, receives the municipality of Mondéjar, in Amoguerra, from Sancho IV on 25 October 1284, a gift that was confirmed by Ferdinand IV to the donees on 25 August 1296 (confirmation document published by Benavides (1860). Their 
María Fernández Coronel, Queen María de Molina's governess, got married very young, at puberty, and was a bountiful mother, although few of her children would never make it as far as adulthood (Layna, 2010: 68). A well-known descendant of her was also her grand-daughter named María Alonso Coronel², daughter of Fernán González Coronel and Sancha Vázquez, who got married to Alonso Pérez de Guzmán, known as the "Good" due to his heroic defence of Tarifa. She was popularly known as the "one of the charred stick" since, according to tradition, feeling lustful desires in the absence of her husband, cauterized her genitals with a burning ember (Serrano Ortega, 2006).

This onomastic coincidence that we have stated above has given rise throughout the centuries to many cases of historiographic confusion. Representative is the one involving Ambrosio de Morales, who asserts at the end of the $16^{\text {th }}$ century that it was well known in Guadalajara that some María Coronel, the one "who made the great feat of the charred stick, is the one who founded in that city a hospital above the fountain, and is buried there at the choir of the Nuns of the Royal Monastery of Santa Clara". Ambrosio de Morales summarizes the confusion between María Fernández Coronel, the governess, and the wife of Guzmán the Good, her granddaughter, recounting by mistake that María Coronel, daughter of Alonso Fernández Coronel, was the founder of the Clarisas monastery of Guadalajara and that she is buried there (Morales, 1586).

Another historiographic confusion, as the one in which Friar Jacobo de Castro is involved in the first half of the $18^{\text {th }}$ century, are even more mistaken as, according to them, María Fernández Coronel, the governess, was married to Juan de la Cerda, who was the husband of her great-granddaughter:

A venerable religious woman left this convent to become Abbess of the Santa Clara convent of Guadalajara, whose name, although unknown, is related to señor Gonçaga, Uvadingo and Arturo; she was daughter of that distinguished heroine María Fernández Coronel, born in Galicia, archbishopric of Santiago, wife of Juan de la Cerda (they say that mother and daughter died and the grave is worshiped as both corpses are incorrupt) (Castro, 1722: 320).

On the other hand, in the Franciscan Martirologio by the monk Arturo, in the edition of Paris of the year 1638 at the expense of Dionysus Moreau's imprente, it is alluded with the following Latin text to María Fernández Coronel's figure:

Guadalajara, Castile, to Our Lady María Fernández Coronel, widow, founder of the Monastery of Guadalajara: which, born of noble lineage, after the death of her husband, right there took the habit of the Order of St. Clare and there stood out in piety, religiosity, virtue and sanctity of life (Arturo, 1638: 286).

son, Alfonso Fernández de Biedma, succeeded his parents in the newly created estate of Mondéjar and was a knight, with a certain fame, during Alfonso Xl's reign and, when the latter was a minor, was Chief Governor of Seville (Moxó, 1974: 239-240).

2 María Alfonso Coronel, grand-daughter of María de Molina's governess, gets married to Alonso Pérez de Guzmán the Good in the city of Seville in 1268, a marriage meaning the relationship with the Guzmán's lineage and the first settlement of a Colonel in Seville. María Alfonso Coronel, who became a widow when aged 42, protects her large fortune, looks after her family, and takes care of her foundation of San Isidoro del Campo. Furthermore, she collaborates with Queen María de Molina when the latter tries to preserve the peace in Andalusia while her grandson Alfonso XI is under age, participating in the meeting that the General Brotherhood holds in Peñaflor on 23 April 1320, in which, among other resolutions, it is agreed to set out the conditions to accept Infante Philip as the king's tutor (Rodríguez Liáñez and Anasagasti Valderrama, 2004: 559-572). 
In the index of this book, when María Fernández Coronel's name is gathered again under the epigraph of July the third, it is annotated the anecdote referred to the greatgranddaughter of our personage, María Fernández Coronel, who threw herself boiling liquid to disfigure her face and to banish in this way the desires of Peter the Cruel. Again the nominal confusion led the author to the identity of two prominent figures of the same lineage separated by three generations. Curiously, the mistake is amended, so in the edition of the same book belonging to the year 1653, in the index, it is suppressed the annotation referred to the legend of the Sevillian María Fernández (Arturo, 1653).

It is, therefore, an onomastic and historiographic confusion that lasts up to the present date in different areas of the academic knowledge, such as the area of the descriptions recorded in archives ${ }^{3}$. And up to this point the confusion of names, which mainly refers, as explained above, to two figures of her own lineage (Layna, 2010: 63).

We will provide below some complementary notes on the governess María Fernández Coronel's descendants. Another direct descendant was her daughter Teresa, who became Abbess of the Clarisas convent founded by María Fernández Coronel in Guadalajara, and who would have an active role in the governess' last years, as analysed below. Likewise a notable descendant was her grandson Alfonso Fernández Coronel, one of the most influential advisers of Alfonso XI (Rodríguez Porto, 2006), married to Elvira Alfonso de Biedma ${ }^{4}$. The daughters of this marriage, who were also great-granddaughters of María Fernández Coronel, the governess, were the ones who claimed before Henry II the rights to the Torija Estate, which would end up passing on to the Mendozas, as many other villages of la Alcarria, in spite of which the Coronel lineage did not disappear from this region, remaining very settled somewhere like Jadraque, very close to Hita. The key stone in the settlement of this lineage in the Alcarria was, without a doubt, the figure of María Fernández Coronel, who had arrived to the village of Guadalajara at that time as the governess of Infanta Isabella, daughter of María de Molina. One of these daughters of Alfonso Fernández Coronel, Mayor, according to the will granted in Buitrago on $12^{\text {th }}$ of April 1407, stipulated to be buried in the Clarisas convent of Guadalajara founded by her great-grandmother, María Fernández Coronel, the governess, dressed up with the nun's habit, also stating that a bust representing her corpse shrouded in the habit should be put beside the epistle (Vieyra de Abreu, 1883).

Apart from the more or less legendary origins that make it depend directly on the Roman emperors, as Barrantes points out in his Ilustraciones de la Casa de Niebla (Barrantes Maldonado, 1998), it seems that the Coronels are a lineage of Galician origin,

3 In a document from the National Historical Archives $(A H N)$, available at the Spanish Archives Website (PARES), the following may be read: Privilege granted by Ferdinand IV of Castile, whereby it is confirmed, in favour of María Fernández Coronel, Queen María de Molina's governess, the allowance given by him of rights, estate and justice of the village of Loranca on 10 January of that same year, and the acceptance and tribute given by the council of Guadalajara to comply with said privilege. Nobility section in the AHN Fernández Coronel, CP. 328, D. 18. Traces of green and red silk thread. Seal missing. On the closed and sealed envelope "of María Fernández Coronel" with handwriting of that time. On the reverse: recovery. This could be the wife of Alonso Pérez de Guzmán, known as Guzmán the Good. Good state of conservation. The confusion remains in the 21st century by the technician in charge of the archive description.

4 Alfonso Fernández Coronel, married to Elvira Alfonso de Biedma, third Lady of Mondéjar, was Lord of Burguillos, Capilla and Aguilar, becoming a nobleman in the beginning of Peter l's reign. However, he would soon lose the monarch's favour, which would lead him to a dramatic end (López de Ayala, 1549). During Alfonso Xl's reign, Alfonso Fernández Coronel had received from the monarch the small village of Torija, in Hita, over which he established a new estate very close to this village, which was passed on, after his unfortunate and tragic death, to the knight Íñigo López de Orozco, who enjoyed Peter l's favour until he moved to the trastamarista side, as a consequence of which he also had a dramatic end after the Battle of Nájera (Moxó, Op. Cit.). 
whose presence in Castile is evidenced by documents from the $12^{\text {th }}$ century materialised in D. Pedro Coronel, Castilian knight who, together with Enrique de Lorena, participates in the reconquest of Portugal (Rodríguez Liáñez and Anasagasti Valderrama, 2004). Therefore, in a first degree, it can be stated that this confusion of names has contributed to the shortage or the absence of monographic works dedicated to the governess' figure, for the benefit of the greater attention paid to some of her female descendants.

\section{IN MARÍA DE MOLINA'S SHADOW}

Queen María de Molina had in her governess María Fernández Coronel a loyal supporter, an unshakeable friendship, a tutor for her daughter Infanta Isabella, in addition to a valuable adviser and confident, something most valuable in such a tumultuous time where there were many testimonies of disloyalty ${ }^{5}$. There are some episodes of the reign in which these abilities were notorious and visible and those are the ones that we are going to analyse below.

The first of these episodes is related to the ambitious and intriguing Lope Díaz de Haro, Lord of Vizcaya. Acknowledging how much María Fernández Coronel influenced on Queen María, he demanded and obtained from Sancho IV that the governess would be sent into exile and her assets would be confiscated. The aim was to bring about a division between the women friends and the monarch and, therefore, to drift the spouses apart for the benefit of the king's favourite and to contribute to the wedding of the king and Guillerma de Montcada (Carmona Ruiz, 2005: 78). None of the two women got carried away by the situation, to which they responded with silence, and María Fernández Coronel was sent by Queen María de Molina to Toro, to look after Infanta Isabella, who was a child at that time. Over time, the Lord of Vizcaya's abuse of authority ended up enervating the impulsive King Sancho, who finally killed Lope Díaz de Haro in Alfaro in 1288. This way, María Fernández Coronel, in exile, recovered her freedom and her assets, which were increased due to the numerous gifts from the king (Layna, 2010: 62-63). This historical episode is a clear example where it was not the authority that gave power to the two women but the silence and the trust in God (Vinyoles and Varela, 1991), waiting patiently until the scales would fall from King Sancho's eyes and he would react as a result of his own certainty (Moreta Velayos, 1996). Queen and governess represent a historical practice that refers to the idea of pathway, relationship based on difference ${ }^{6}$. Feelings manage to focus on details of the transformation of reality to unmask the identity pairing between history and power, ${ }^{7}$ determining the course of history as a reflection of power.

Since María Fernández Coronel stayed with Infanta Isabella in Aragon for long periods, she also acted as skilled diplomatic agent, informing the queen of the political fluctuations of the reign. Her warnings and advice allowed Queen María de Molina to avoid serious problems for Castile (Layna, 2010: 63). In the year 1293 the "interviews" of Logroño take place, an important diplomatic act for which many preparations were organised. Not only the attendance of the Aragonese King James II was expected, but also of his rival in Sicily,

5 Together with the figure of the governess was also the queen's mistress, María Domínguez (Gaibrois de Ballesteros, 2010: 23).

6 "the one referring to the masculine genealogy, inspired in the events granting power over the world and control over other people's lives, and which for us women is restrictive [...] with men, where feelings show aspects of the change of reality to clear up the identity confusion between history and power and, therefore, to gather up, whilst staying away from the history reduced to power" (Minguzzi, 2001: 84).

7 "Se entendía que lo que tenía poder hacía historia y que las instancias del poder sostenían, a su vez, la verdad histórica" (Rivera Garretas, 2005: 63). 
Charles of Anjou, and other distinguished delegates who were going to settle their lawsuits before Sancho of Castile. That political adventure went on for three weeks, in which Charles and James II started to get along with each other behind Sancho IV's back, and left the Castilian coffers reduced, since we know that María Fernández Coronel "lent four thousand maravedís to the king in Logroño, so that he could give them to Bernalt of Soria" (Gaibrois, 1967: 88-90).

In the year 1294 an Aragonese delegation arrived to Valladolid, headed by María Fernández Coronel, governess of Infanta Isabella, for the purpose of calming down Sancho given the rumours of negotiations between James II and Charles II of Anjou. James II had chosen the loyal infanta's mistress as ambassador with the clear intention to deceive the Castilian monarchs, as he knew very well the esteem they felt for her ${ }^{8}$. This is the second occasion in which a historical figure, in this case King James II, takes advantage of the proximity of the governess and the monarchs for his own political interests. Mercedes Gaibrois suggests that María Fernández Coronel, woman of a certain age and with experience, should have not been deceived in respect of King James' international politics. However, she disguised, for discretion and compassion, before the ill king of Castile, only trusting María de Molina who, in those circumstances, could not do anything either to keep that shadow of Castilian-Aragonese union (Gaibrois, 1967: 100-101). Thus, all the break-up procedure with Aragon remains between the queen and María Fernández Coronel to avoid King Sancho's suffering (Gaibrois, 1967: 102).

The fusion of the queen and her governess remains until the monarch's last years. María de Molina appoints as executors two friends of proven loyalty, colleagues of her in the times of sorrow: María Fernández Coronel and Nuño Pérez de Monroy, her chancellor, Archdeacon of Campos and Abbot of Santander (Larriba Baciero, 1995).

\section{IN THE INFANTA ISABELLA'S SHADOW}

The year following her marriage, Queen María de Molina is pregnant of her first child and Sancho accompanies her in the village of Toro, where Infanta Isabella is born soon after, and María entrusts the child's care to her former governess María Fernández Coronel, who would become a second mother for the newly born (Gaibrois, 1967: 24; Carmona Ruiz, 2005: 47). The infanta would grow up with her until the day of her wedding vows (Flórez, 1770).

On the $1^{\text {st }}$ of October 1291, Sancho IV and James II head for the city of Soria, where the governess and the infanta were waiting, to celebrate with great honour the wedding of the Aragonese monarch and Infanta Isabella. The kings of Castile and Aragon spend together the Christmas time of that same year. Then, once the festivities and the treaties have concluded, Sancho and María must return to Castile. The queen has to say goodbye, not knowing for how long, to her daughter Isabella, but leaves her under the custody of her kind friend María Fernández Coronel (Gaibrois, 1967: 79). It is then when Infanta Isabella moves to the Aragonese court with María Fernández Coronel, until she reaches the nubile age of twelve years (Carmona Ruiz, 2005: 113).

Five years would last the Aragonese adventure of the infanta and the governess, as already in 1296 Queen María de Molina receives her daughter, aged 13, in Castile. The governess María Fernández Coronel, already an elderly woman, comes with her. This return of Infanta Isabella represented for Castile the unfortunate epilogue of the CastilianAragonese alliance that had taken place in times of Sancho IV (Gaibrois 1967: 125).

8 "For her part, it is very likely that María Fernández Coronel travelled to Castile ignoring that what the Aragonese king really pretended was to leave Isabella and to marry Blanche of Naples, daughter of Charles II" (Carmona Ruiz, 2005: 124-125). 
When Sancho the Brave dies on the $25^{\text {th }}$ of April 1295, María de Molina had to govern the reign jointly with Infante Henry, as tutors of Ferdinand IV, aged eight. Those were times of continuous riots, and therefore the queen was forced to travel her and there to calm things down. In order to have more freedom of action, she decided to send her daughters Beatrice and Isabella to Guadalajara and the governess María Fernández Coronel to look after them. Since then, the three women stayed, with the exception of short intervals, for many years in the village in those days of Guadalajara ${ }^{9}$. Beatrice would finally get married to King Alfonso IV of Portugal. And we can state that the governess and Infanta Isabella lived mostly in Guadalajara since 1296.

In 1309 Infanta Isabella accompanies Queen María de Molina, already sickly, travelling with the court around Castilian cities and villages until she is 26 years old and gets married to John, Duke of Brittany, in Burgos with great ceremony by the end of January 1311. The newlyweds went to Limoges, did not have children and, once the duke had died, Infanta Isabella, having died also María de Molina, lived her last days in Guadalajara, according to chroniclers such as Núñez de Castro. Therefore, in the year 1309 Isabella had left in Guadalajara her governess, already old and exhausted, who finally died that same year.

The wish to serve God and to benefit the neighbours who were in need of protection, made María Fernández Coronel and Infanta Isabella found and supply women convents, where the admitted women were freed from the misery and the attacks to their honour, whilst giving example and worshiping the divinity with their devotion (Sánchez Ameijeiras, 2005). The role of Infanta Isabella is performed encouraged by her governess María Fernández Coronel's attitude. The latter was the one who had the initiative to build a Clarisas nuns convent, supplying the same sufficiently so that they could live without scarcity, and taking into a new building those who lived precariously in the convent of la Cuesta de San Miguel, which had been founded by Infanta Berenguela, daughter of Alfonso X (Layna, 2010: 65-67).

María Fernández Coronel bought some houses in the congregation of San Andrés, right in the centre of the Jewish quarter of Guadalajara, from Sancha, widow of the Jewish Yahuda, with farmyards, attached vegetable gardens and shops ${ }^{10}$. After the purchase in the year 1299, they started the construction of a convent and a church, thus appearing the Royal Convent of Santa Clara of Guadalajara. Other neighbours of Guadalajara also sold or gave their lands in order to create a wide plot for this foundation, which would grow rich and powerful throughout the Middle Ages. The nuns would move from the Cuesta de San Miguel to the new location in 1307 (Herrera Casado, 1997; Larumbe and Román, 2004). The house bought by María Fernández Coronel from Sancha cost 1800 maravedís and later she would acquire another house owned by Sancha herself —widow for the second time of the Jewish Samuel Camhy-, this one under the convent's name (Cantera Burgos and Carrete Parrondo, 1974).

In the following years, she continued to acquire properties for the convent, as recorded in the list of assets left by her to the nuns when she granted her last will and testament, as we will examine below. And although the ecclesiastical letters authorizing the founding of the convent were granted in the name of Infanta Isabella, the truth is that the weight of the task felt on María Fernández, as evidenced by the documentary language with expressions such as María Fernández "builds" or "wants to build" the convent of Santa Clara, as stated on documents signed by the infanta herself (Layna, 2010:67).

9 Layna refers that the Infantas' bridge beside the tower of El Alamín remains as a memory of their stay (Layna Serrano, 2010: 59).

10 This fact could also be seen as an expression of the "convert dissimulation". Véase Pérez Zagorín, 1990. 


\section{THE SHADOW OF DEATH}

By the year 1309, as we have stated above, the elderly governess María Fernández Coronel, unable to follow Infanta Isabella due to her ailments as she had been doing until then, stays in Guadalajara fully dedicated to the supply and the construction of the Clarisas convent, a building that history awards to her although she always had Infanta Isabella's support. The elderly María Fernández Coronel was living at that time in a house owned by her located in the Cuesta de San Miguel and she probably continued there longer until she moved to the Clarisas convent with her daughter Teresa ${ }^{11}$, abbess of the same. Shortly before she died, she reasserted her role as historical agent, founding a hospital for pilgrims that would shelter those passing by Guadalajara, with five beds and a monthly rent of 25 reales and three and half bushels of wheat, the administration of which would be on the account of the convent.

María Fernández Coronel died that same year 1309. María, according to Layna, should have died between July and September 1309 because, as evidenced by the privileges granted by the council to the convent, on the $28^{\text {th }}$ of that month they referred to the monastery that María Fernández "builds", thus evidencing that she was still alive. However, on the first day of September, Ferrand Pérez, Infanta Isabella's trustworthy man, provided Abbess Teresa and the nuns with a letter written by María, stating the list of assets that she gave to the convent in perpetuity, and on the sixteenth of October of that same year the abbess and the nuns granted a power of attorney before the notary public Juan Guillén in favour of Gil Martínez, Governor of Guadalajara appointed by the infanta and lady of the village, so that on behalf of them he could take possession of those assets. This proves that the donor had already died on 10 September.

We know that María Fernández Coronel gave to the convent the houses in the congregation of San Andrés where the monastery was located, with the dwellings that she bought and with the vegetable gardens, some hawthorns and windmills in the meadow of the Henares, in addition to those in other municipalities such as Alovera, Illescas, Benalaque, Taracena, Alarilla, Marchamalo or Hita. María Fernández Coronel was buried in the choir of the Clarisas convent. Some building works carried out in the $17^{\text {th }}$ century showed that her corpse remained in perfect condition. When the Clarisas nuns left the convent in 1912 and the latter was demolished, the Provincial Commission for Monuments looked after the founder's corpse. After the heavy damages and robberies in the civil war, in August 1936, the Professor of Geography and History Gabriel María Vergara took the corpse to the Secondary Education Institute of Guadalajara where, shortly afterwards, the students affiliated with the FUE (university student federation) student union destroyed the founder's remains.

After María Fernández Coronel's death, the Clarisas convent, being Elvira Fernández already the abbess, authorizes her descendant Alonso Fernández Coronel —grandson of the founder- ${ }^{12}$, his wife Elvira of Biedma and their children and descendants, to be buried at the convent's church. The identity of names and surnames, the fact that Alonso Fernández Coronel, grandson of María from Guadalajara and father of María from Seville, was buried in the convent's church of Santa Clara of Guadalajara, that these two women lived for many years in their old ages in Clarisas nuns convents, that both largely favoured the same religious order and finally, that their respective body remains were preserved until recent years, are reasons leading —-together with the onomastic confusion referred to in the

11 Another daughter of María Fernández Coronel took vows in the Clarisas Convent of Toro.

12 Alonso from Aguilar favoured the convent with significant donations while he was alive (Layna Serrano, 2010: 63, 68, 70, 71 and 75). 
beginning - to the accepted confusion perpetuated by the chroniclers of that time and the subsequent historiographers.

\section{AS EPILOGUE}

The present work has intended, at a first instance, to clarify the "shadow" hunging over this female historical character, with the aim of giving visibility to María Fernández Coronel, Queen María de Molina's governess, as a leading historical agent, thus rescuing her from her role as supporting actress in the Hispanic Medieval world. In opposition to the usual darkening thrown by male genealogical history, her role as historical agent remains opaque due to the superposition of other female figures who make the clarification of her vital history difficult from beginning to end -Queen María de Molina herself, her daughter Infanta Isabella, in addition to the women of her lineage with the same name and surnames-, hence leading to the confusion analysed between chroniclers and historiographers.

The historical episodes occurred during María de Molina's reign, in which María Fernández Coronel actively and discreetly participated, make the figure of the governess to withdraw from the history-power pairing. It was not the authority that made her an agent and creator of a historical language, but abilities such as the silence, the piety, the meditation, feelings projected over the details of the reality in order to transform the latter. Therefore, the historical itinerary drawn by María Fernández Coronel substantiates the relation based on difference. We have tried to reconstruct her vital path in this work based on fragments, evidencing how she and her acts determined the course of history as reflection of power. Recalling Marirì Martinengo's words, diving into the chiaroscuro of this historical creature has allowed a more feminine way to "make history", shifting from the great woman to the common woman, putting aside the leading role in favour of a life's story in which the creator of the historical language ends up identifying and recognising herself.

\section{REFERENCES}

Álvarez, M. T. (2003), Ellas mismas: mujeres que han hecho historia contra viento y marea, Madrid, La Esfera de los libros.

Arana de Valflora, F. (1791), Hijos de Sevilla ilustres en Santidad..., Sevilla, Imprenta de Vázquez e Hidalgo.

Arauz Mercado, D. (2007), “Las mujeres medievales en los reinos hispánicos: 3 personajes en relación a la política y la literatura", Revista Digital de la Universidad Autónoma de Zacatecas, 3(1), pp. 1-23.

Arteaga, A. (2005), María de Molina, tres coronas medievales, Barcelona, Martínez Roca.

Arturo (1638), Martyrologium franciscanum in quo sancti, beati, alliique servi Dei, martyres, pontífices, confesores, ac virgines..., París, Moreau.

- (1653), Martyrologium franciscanum in quo sancti, beati, alliique servi Dei, martyres, pontífices, confesores, ac virgines..., París, Edmundo Couterot.

Barrantes Maldonado, P. (1998), Ilustraciones de la Casa de Niebla, Cádiz, Universidad.

Benavides, A. (1860), Memorias de Don Fernando IV de Castilla, vol II. Coleccion Diplomática, Madrid, Imprenta de José Rodríguez.

Cantera Burgos, F. and Carrete Parrondo, C. (1974), "Las juderías medievales en la provincia de Guadalajara", Sefarad, 34(1), pp. 43-78.

Carmona Ruiz, M. A. (2005), María de Molina, Barcelona, Plaza y Janés.

Castro, F. J. (1722), Primera parte del Árbol Cronológico de la Santa Provincia de Santiago, Salamanca, Francisco García Onorato y San Miguel.

Flórez, E. (1770), Memorias de las reinas católicas, Madrid, Antonio Marín.

Fuente Pérez, M. J. (2003), Reinas medievales en los reinos hispánicos, Madrid, La Esfera de los Libros. 
Gaibrois de Ballesteros, M. (1967), María de Molina, tres veces reina, Madrid, EspasaCalpe.

- (2010), María de Molina, Pamplona, Urgoiti editores.

Herrera Casado, A. (1997), Monasterios medievales de Guadalajara: una guía para conocerlos y visitarlos, Guadalajara, Aache.

Larriba Baciero, M. (1995), "El testamento de María de Molina", Signo. Revista de historia de la cultura escrita, 2, pp. 201-212.

Larumbe, M. and Román Pastor, C. (2004), Arquitectura y urbanismo en la provincia de Guadalajara, Consejería de Cultura Castilla la Mancha.

Layna Serrano, F. (2010), Los conventos antiguos de Guadalajara, Guadalajara, Aache.

López de Ayala, P. (1549), Crónica del Rey don Pedro, Sevilla, Jacome Cromberger.

Márquez de la Plata, V. and Valero de Bernabé, L. (2000), Reinas medievales españolas, Madrid, Alderaban.

Matute y Gaviria, J. (1827), Bosquejo de itálica o apuntes que juntaba para su historia, Sevilla, Imprenta de D. Mariano Caro.

Minguzzi, L. (2001), "La strada si crea caminando", in Cambia il mondo e cambia la storia, Atti del Convegno della Comunità di pratica e riflessione pedagógica e di ricerca storica, Milán, Marina.

Morales, A. (1586), Discurso de la verdadera descendencia del glorioso Doctor santo Domingo, y como tuuo su origen de la Ilustrissima casa de Guzmán, Madrid.

Moreri, L. (1753), El gran diccionario histórico o Miscelánea curiosa..., Hermanos de Tournes. Moreta Velayos, S. (1995), "Notas sobre el franciscanismo y el dominicanismo de Sancho IV y María de Molina", in VI Semana de Estudios Medievales: Nájera, 31 de julio al 4 de agosto de 1995, Logroño, Instituto de Estudios Riojanos.

Moxó, S. (1974), "La sociedad en la Alcarria durante la época del Arcipreste", Boletín de la Real Academia de la Historia, CLXXI(II), pp. 239-240.

Núñez de Castro, A. (1653), Historia eclesiástica y seglar de la muy noble y muy leal ciudad de Guadalaxara, Madrid, Pablo de Val.

Ortiz de Zúñiga, D. (1796), Anales eclesiásticos y seculares de la muy noble y muy leal ciudad de Sevilla, Madrid, Imprenta Real.

Pérez Arribas, A. (2000), Historia de Torija, Guadalajara, Aache.

Pérez Zagorín (1990), Ways of lying: dissimulation, persecution and conformity in early modern Europe, Cambridge Mass., Harvard University Press.

Real Monasterio de Santa Inés de Sevilla (1930), Vida, hechos y milagros de la ilustre y heroica Doña María Coronel: mujer que fue del infante D. Juan de la Cerda, y venerable fundadora y abadesa del Real monasterio de Santa Inés de Sevilla, Sevilla, Divina Pastora.

Rivera Garretas, M. M. (2005), La diferencia sexual en la Historia, Valencia, Universidad.

Rodríguez Liáñez, L. and Anasagasti Valderrama, A. M. (2004), "Aldonza Coronel. Esposa de dos Alvar Pérez de Guzmán", HID, 31, pp. 559-572.

Rodríguez Porto, R. M. (2006), "María de Molina y la educación de Alfonso XI: las semblanzas de reyes del ms. 7415 de la Biblioteca Nacional", Quintana: revista de estudios do Departamento de Historia da Arte, 5, pp. 219-231.

Sánchez Ameijeiras, R. (2005), "Cultura visual en tiempos de María de Molina: poder, devoción y doctrina", in El conocimiento del pasado: una herramienta para la igualdad, Salamanca, Plaza Universitaria.

Sánchez Saus, R. (1989), Caballería y linaje en la Sevilla medieval: estudio genealógico y social, Cádiz, Servicio de publicaciones de la Universidad.

- (2009), Las élites políticas bajo los Trastámara: poder y sociedad en la Sevilla del siglo $X I V$, Sevilla, Universidad. 
Serrano Ortega, M. (2006), Monumentos de los pueblos de la provincia de Sevilla, Sevilla, Universidad.

Valle Curieses, R. (2000), María de Molina: el soberano ejercicio de la concordia: (12601321), Madrid, Alderaban.

Vieyra de Abreu, C. (1883), Doña María Coronel: estudio histórico acerca de la autenticidad de sus restos, Madrid, Alfredo Alonso.

Vinyoles i Vidal, T. and Varela Rodríguez, E. (1991), "Religiosidad y moral social en la práctica diaria de las mujeres en los últimos siglos medievales", in Religiosidad femenina: expectativas y realidades (siglos VIII-XVIII), Madrid, Laya. 